Animal

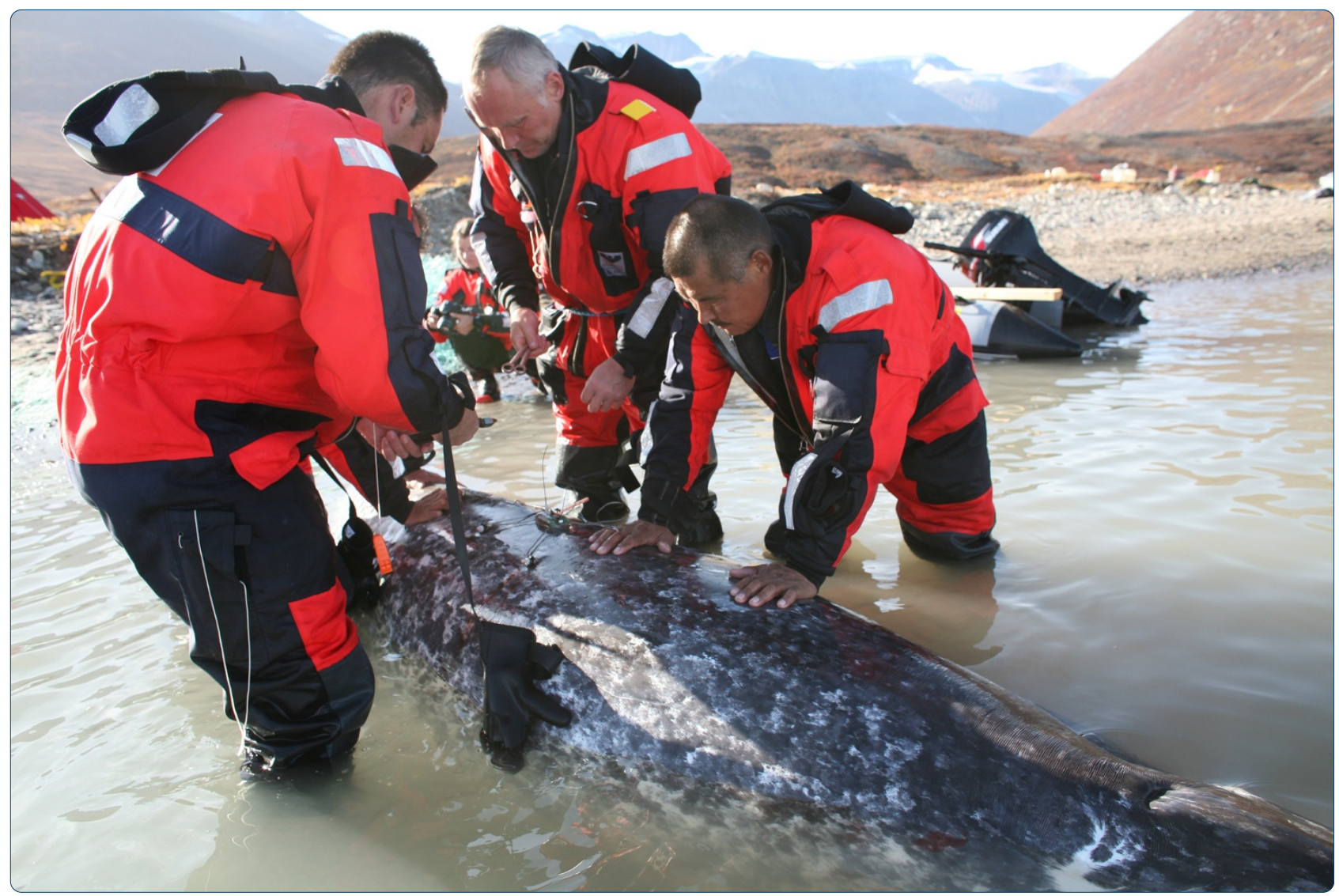

\title{
Stomach temperature of narwhals (Monodon monoceros) during feeding events
}

Heide-Jørgensen et al. 


\title{
Stomach temperature of narwhals (Monodon monoceros) during feeding events
}

\author{
Mads Peter Heide-Jørgensen ${ }^{1 *}$, Nynne H Nielsen, Rikke G Hansen and Susanna B Blackwell ${ }^{2}$
}

\begin{abstract}
Background: Information on the feeding rate by free-ranging odontocetes is necessary for assessing potential conflicts with fishing activities. One way of obtaining a proxy for feeding events in homeothermic predators is to measure stomach temperature, which drops during prey ingestion. In this study, stomach temperature pills (STPs) were deployed in eight narwhals (Monodon monoceros) in East Greenland (2012-2013). A coded message with information on the temperature was transmitted from the STP and received and relayed by a satellite-linked radio transmitter attached to the back of the whale. Meal size and prey composition were estimated from samples collected from the Inuit hunt of narwhals.

Results: Two STPs provided data for 7.9 and 17.3 days and six STPs were rejected within $48 \mathrm{~h}$. All whales had their first ingestion event between 20 min and $14 \mathrm{~h}$ after handling and release. The mean duration of the STP deployments was $93 \mathrm{~h}(\mathrm{SD}=164)$ and duration was positively correlated with the time between the deployment and the first ingestion event, but did not seem to be affected by the ingestion rate. The average stomach temperature during non-feeding periods was $35.5^{\circ} \mathrm{C}$. During ingestion events, the temperature dropped, on average, to $31.6^{\circ} \mathrm{C}$. Ingestion events took place at depths of 13 to $850 \mathrm{~m}$ with a mean depth of $286 \mathrm{~m}(n=126, S D=195)$. The mean number of detected ingestion events was $9.9(S D=4.2)$ per $24 \mathrm{~h}$. The average duration of the ingestion events was $9.6 \mathrm{~min}(\mathrm{SD}=4.1)$ and it was not correlated with the size of the drop in temperature or the depth of the feeding dive $\left(r^{2}=0.03\right.$ and 0.004$)$ and there was no diel pattern in the ingestion events. The average mass of the stomach contents was $\sim 2 \mathrm{~kg}$. No effect was detected on narwhal behavior as a result of the instrumentation.
\end{abstract}

Conclusions: Stomach temperature telemetry offers the possibility of directly estimating narwhal feeding rates over periods of weeks. The information obtained, however, would need to be validated to account for mariposa and to gauge whether feeding events could be missed by the STPS.

Keywords: Arctic, East Greenland, Feeding, Narwhal, Prey consumption, Stomach contents, Stomach temperature

\section{Background}

To understand the interaction between marine top predators and their prey in marine ecosystems, two pieces of information are critical: i) an estimate of the amount and frequency of prey consumption, and ii) knowledge of the geographic locations and preferred water depths where such consumption occurs. In the case of freeranging cetaceans, prey consumption has traditionally been assessed by theoretical calculations of energy demands during growth and activity, usually with first order approximations and analogies to seals and terrestrial mammals [1]. In a few instances, it has been

\footnotetext{
*Correspondence: mhj@ghsdk.dk

'Greenland Institute of Natural Resources, Box 570, DK-3900 Nuuk, Greenland Full list of author information is available at the end of the article
}

possible to observe prey consumption directly using captive cetaceans [2-4]. For obvious reasons, it is difficult to use those observations for inferences on feeding rates that would apply to free-ranging cetaceans.

One possible proxy for monitoring the frequency of prey intake in cetaceans is through measurements of changes in stomach temperature as ingestion of cold prey results in a temperature drop in the otherwise homeothermic whale [5]. In the past, stomach temperatures of pinnipeds have been measured with a thermistor pill that emits a signal where the intervals between consecutive pulses indicate the temperature change. This has been done in five pinniped species but has not been tested previously on any cetaceans [6-10]. 
The narwhal (Monodon monoceros) is a 4 to $5 \mathrm{~m}$ long Arctic odontocete that attains a body mass of up to $1,800 \mathrm{~kg}$ [11]. Narwhals inhabit waters along East and West Greenland and in northern Canada where they feed on relatively few prey species including the commercially important Greenland halibut (Reinhardtius hippoglossoides) $[12,13]$. An expanding offshore fishery for Greenland halibut overlaps with the winter distribution of narwhals and it is therefore important to develop methods to estimate prey consumption by narwhals in order to assess the potential for competition with the fishery.

In the study presented here, stomach pills that transmit coded temperature signals were tested in narwhals, and the feasibility of using this approach to study the foraging behavior and foraging ecology of free-ranging cetaceans was evaluated.

\section{Results and discussion}

A total of eight narwhals (six males and two females) were equipped with stomach temperature pills (STPs) and satellite transmitters in August 2012 and August 2013 at Hjørnedal in Scoresby Sound, East Greenland (Figures 1 and 2). Four of the eight STPs were likely regurgitated within $24 \mathrm{~h}$ (three in 2012, one in 2013). Only two STPs lasted longer than $48 \mathrm{~h}$, providing data for 191 and $414 \mathrm{~h}$ (7.9 and 17.3 days; Table 1). Contact with all eight whales was maintained for $>1$ month after instrumentation with the dorsally-mounted satellite transmitter. Ingestion or feeding events were identified by sudden drops in temperature $[9,14]$. All whales had their first ingestion event $20 \mathrm{~min}$ to $14 \mathrm{~h}$ after being handled and released (mean $=4.3 \mathrm{~h}, \mathrm{SD}=4.1$; Table 1$)$. The duration of the eight STP records was positively correlated with the time between the deployment and the first ingestion event, i.e., the longer the interval between deployment and the first ingestion event the longer the duration of the record (ANOVA $P=0.002$ ), but duration did not seem to be affected by the ingestion rate.

The average stomach temperature of the eight whales during non-feeding periods was $35.5^{\circ} \mathrm{C}$ (range $34.5-36.2^{\circ} \mathrm{C}$ ). Feeding events were identified by sudden drops in temperature. During ingestion events the temperature, on average, dropped to $31.6^{\circ} \mathrm{C}$, but it occasionally dropped to below $20^{\circ} \mathrm{C}(\mathrm{n}=3)$. The temperature drop was followed by an asymptotic recovery of $9.5 \mathrm{~min}(\mathrm{SD}=3.9)$ on average. In some cases, the temperature drop seemed to indicate a single well-defined ingestion event (Figure 3A), whereas in other cases there appeared to be several consecutive ingestion events that were not as easily discernible with a recovery time lasting up to $4 \mathrm{~h}$ (Figure $3 \mathrm{~B}$ ). The enumeration of ingestion events is therefore somewhat uncertain and could potentially be biased by both missed events from small meals undetected by the STP and false positive records from mariposa (ingestion of sea water).

On average, the estimated number of detected ingestion events for the eight whales was $9.9(\mathrm{SD}=4.2)$ per $24 \mathrm{~h}$ and this did not differ between the two years. There was no significant correlation between ingestion rates and duration of events at larger body mass where body mass was estimated from standard nonlinear regression of mass vs.

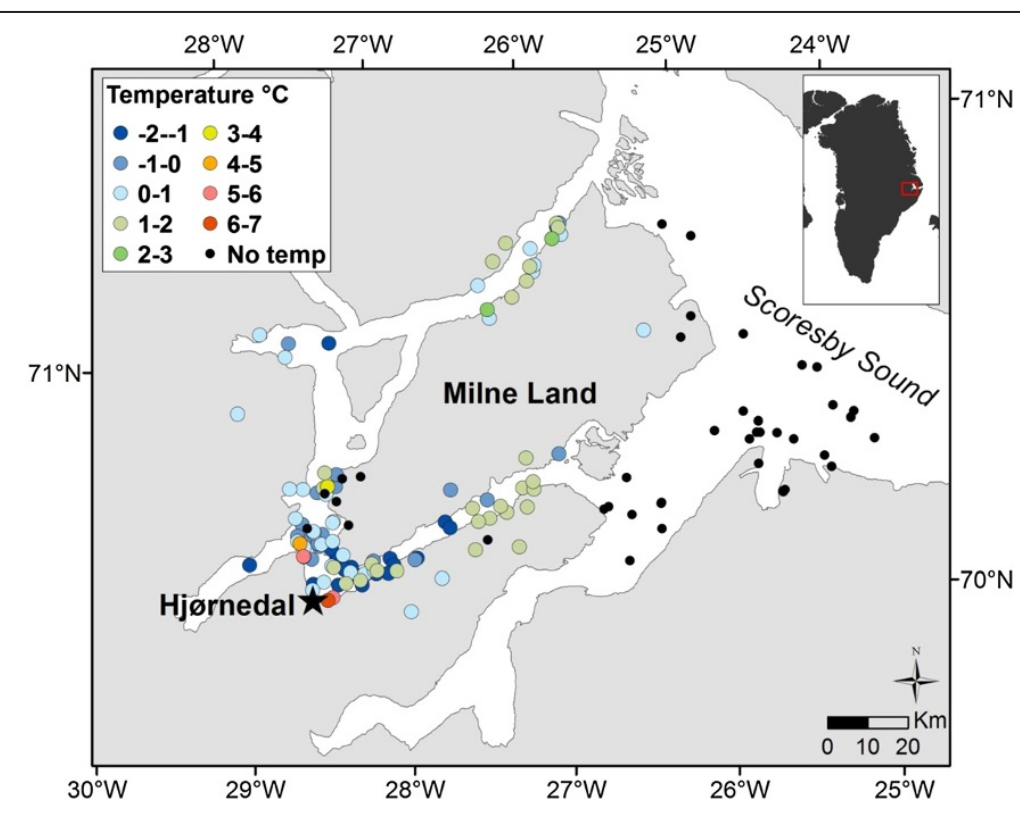

Figure 1 Locality used for whale captures (Hjørnedal) and positions where drops in stomach temperature of the instrumented whales took place (i.e., presumed feeding locations). Locations on land are due to low precision of the positions closest in time to the stomach temperature drops. The water temperatures at the locations and depths of the ingestion events were known for some of the locations and are shown as a color-graduated symbol. 


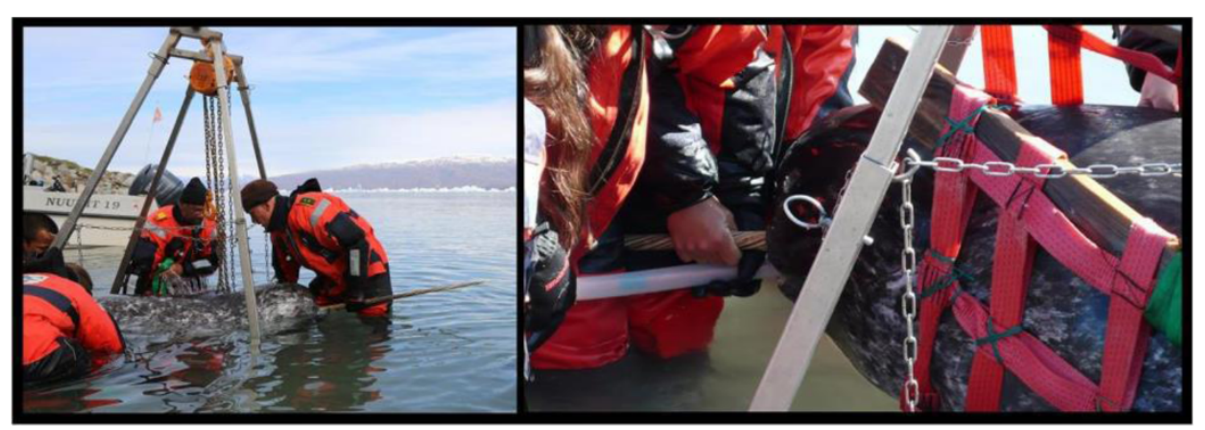

Figure 2 Handling of a narwhal during administration of stomach temperature pills. A cradle was used to lift the head of the whale out of the water before the intubation tube with the STP was inserted into the esophagus.

standard length (Figure 4). Duration of ingestion events was not correlated to the drop in temperature or the depth of the feeding dive $\left(\mathrm{r}^{2}=0.03, \mathrm{n}=163\right.$, and $\mathrm{r}^{2}=0.004, \mathrm{n}=$ 153) and there was no diel pattern in the ingestion events (Rayleigh z-test, $P=0.498$ ), with $48 \%$ of events taking place between 18:00 and 6:00 h GMT. The two whales with STP records $>100$ h did not show significant individual diurnal patterns (\#22850, $P=0.913$ and $\# 3965, P=0.19$ ).

Positions of the whales close to the time of temperature drops indicate that feeding may have occurred at several locations in Scoresby Sound, during both day and night in August (Figure 1). The surrounding water temperature at the ingestion events (as recorded by the animals' satellite tag, see Methods) varied between -1.6 and $+6.9^{\circ} \mathrm{C}$. Although water temperatures were not available for all ingestion events, the range of obtained temperatures $(-1.6$ to $+6.9^{\circ} \mathrm{C}$ ) at the ingestion sites included the entire range of seawater temperatures that can be expected in Scoresby Sound in August, indicating that the narwhals in Scoresby Sound use habitats with a wide range of physical conditions or characteristics.

Exceptionally warm $\left(>1.2^{\circ} \mathrm{C}\right)$ water temperatures $(\mathrm{n}=18$, mean $=5.0^{\circ} \mathrm{C}, \mathrm{SD}=1.9$ ) were invariably recorded when the ingestion events took place at depths of $<18 \mathrm{~m}$ and the whales were in the inner part of the fjord system close to river outlets (mean $=6.8 \mathrm{~m}, \mathrm{SD}=5.9$, Figure 5 ). The warm water temperatures can only be found at river outlets and some of those records were from the river adjacent to the capture site at Hjørnedal (Figure 1).

There was no correlation between water temperature and the recovery of the stomach temperatures during ingestion events $\left(r^{2}=0.02, n=140\right)$ and it could not be resolved whether ingestions in shallow and warm water represent feeding events or mariposa. Ingestion events in warm and shallow water are unlikely to include the normal narwhal prey items and if mariposa occurs it seems unlikely to occur in deep dives. If these 18 ingestions in exceptionally warm water are excluded, the average depths of the feeding events in 2013 ranged from 13 to $850 \mathrm{~m}$ with a mean depth of $286 \mathrm{~m}(\mathrm{n}=126, \mathrm{SD}=195)$. The large standard deviation of the mean depth at ingestion events indicates that feeding did not target specific depths.

A total of 30 alimentary tracts from narwhals killed by local Greenlanders (18 in nets and 12 shot) during August 2010-2013 at Hjørnedal were examined for prey items. The cardiac part of the stomach and the intestine included only fluid and highly digested prey and never contained fresh prey items. Only 12 of the extended esophagi had fresh and/or recognizable remains with an average mass of $2.09 \mathrm{~kg}(\mathrm{SD}=1.26)$. The percentage of whales with empty stomachs was higher for those caught in nets (56\%) compared to the shot whales (42\%) indicating that vomiting during the chase before being shot did not result in an elevated proportion of empty stomachs compared to those whales that drowned in nets $\left(\chi^{2} P=0.71\right)$. The identified prey items were beaks and/or body parts from squid (Gonatus sp.), otoliths, vertebrae, and flesh from polar cod (Boreogadus glacialis) and shrimp remains (Pandalus or Crangon sp.). Squid beaks were found in all stomachs and since squid are typical mid-water animals $[15,16]$ this suggests that most of the ingestion events detected by the STP likely involved squid.

Based on regression equations for Gonatus spp. [17] and polar cod [12] it was estimated that all the squid beaks and otoliths from the narwhal stomachs came from squid and polar cod with individual masses $<100 \mathrm{~g}$. It is not known if each feeding event was comprised by one individual prey item of mass $<100 \mathrm{~g}$, or instead several prey items were ingested simultaneously or in quick succession.

The temperature drops and the recovery times to normal body temperature varied between events, probably reflecting the size and type of the prey ingested. In this study it is assumed that primarily smaller prey items were ingested (i.e., fish and squid of less than $0.1 \mathrm{~kg}$ ) and the pattern of temperature drops and recovery times would probably look different for a narwhal stock that is feeding on larger prey items like Greenland halibut.

The average recovery time of the stomach temperature after ingestion of cold prey was $\sim 10$ min $(\mathrm{SD}=4.2)$, 
Table 1 Summary statistics for eight narwhals instrumented with stomach temperature pills (STPs) in August 2012 and 2013

\begin{tabular}{|c|c|c|c|c|c|c|c|c|c|c|c|c|c|c|c|}
\hline \multirow[t]{2}{*}{ Year } & \multirow[t]{2}{*}{$\begin{array}{l}\text { Whale } \\
\text { ID no. }\end{array}$} & \multirow[t]{2}{*}{ Sex } & \multirow[t]{2}{*}{$\begin{array}{l}\text { Length } \\
\mathrm{cm}\end{array}$} & \multirow[t]{2}{*}{$\begin{array}{c}\text { Estimated } \\
\text { mass } \\
\text { kg }\end{array}$} & \multirow[t]{2}{*}{$\begin{array}{l}\text { Duration } \\
\text { of STP } \\
\text { record }\end{array}$} & \multirow[t]{2}{*}{$\begin{array}{c}\text { Duration of } \\
\text { contact } \\
\text { with satellite } \\
\text { transmitter } \\
\text { Days }\end{array}$} & \multirow[t]{2}{*}{$\begin{array}{c}\text { Temperature } \\
\text { drop/threshold } \\
\text { of STP } \\
{ }^{\circ} \mathrm{C}\end{array}$} & \multirow[t]{2}{*}{$\begin{array}{l}\text { Time between } \\
\text { release and } \\
\text { first feeding } \\
\text { event } \\
\text { Minutes }\end{array}$} & \multirow[t]{2}{*}{$\begin{array}{c}\text { Average } \\
\text { temperature, } \\
\text { non-feeding } \\
{ }^{\circ} \mathrm{C}(\mathrm{n})\end{array}$} & \multirow[t]{2}{*}{$\begin{array}{c}\text { Lowest } \\
\text { temperature } \\
\text { during } \\
\text { feeding } \\
\text { events } \\
{ }^{\circ} \mathrm{C}\end{array}$} & \multirow[t]{2}{*}{$\begin{array}{c}\text { Average } \\
\text { temperature } \\
\text { during } \\
\text { feeding } \\
\text { events } \\
{ }^{\circ} \mathrm{C}\end{array}$} & \multirow[t]{2}{*}{$\begin{array}{c}\begin{array}{c}\text { Average } \\
\text { duration } \\
\text { of feeding } \\
\text { events }\end{array} \\
\text { Minutes }\end{array}$} & \multirow[t]{2}{*}{$\begin{array}{c}\begin{array}{c}\text { Feeding } \\
\text { events }\end{array} \\
\text { n }\end{array}$} & \multirow{2}{*}{$\begin{array}{l}\text { Feeding } \\
\text { rate }\end{array}$} & \multirow[t]{2}{*}{$\begin{array}{c}\text { Range of } \\
\text { depths at } \\
\text { feeding }\end{array}$} \\
\hline & & & & & & & & & & & & & & & \\
\hline \multirow[t]{4}{*}{2012} & 22849 & $M$ & 335 & 700 & 15 & 42 & $10 / 33$ & 133 & $34.5(490)$ & 25.0 & 31.6 & 3.3 & 5 & 8.0 & $40-216$ \\
\hline & 22850 & M & 400 & 1,028 & 414 & 45 & $5 / 33$ & 829 & $36.2(11,700)$ & 24.0 & 30.2 & 10.7 & 45 & 2.6 & $23-553$ \\
\hline & 22853 & M & 278 & 467 & 10 & 45 & $10 / 33$ & 171 & $35.4(375)$ & 16.5 & 31.2 & 7.5 & 2 & 4.8 & $38-166$ \\
\hline & 24638 & $\mathrm{~F}$ & 400 & 867 & 13 & 36 & $5 / 33$ & 321 & $35.4(410)$ & 23.4 & 29.6 & 6.2 & 8 & 14.8 & $3-252$ \\
\hline \multirow[t]{4}{*}{2013} & 3963 & M & 400 & 1,028 & 24 & 80 & $0.6 / 34$ & 37 & $35.2(1,117)$ & 10.5 & 29.5 & 9.5 & 13 & 13.0 & $0-240$ \\
\hline & 3964 & M & 356 & 799 & 30 & 84 & $0.6 / 33$ & 161 & $35.5(1,285)$ & 29.0 & 33.3 & 13.7 & 18 & 14.4 & 13-383 \\
\hline & 3965 & $\mathrm{~F}$ & 420 & 959 & 191 & 83 & $0.6 / 34$ & 362 & $35.8(8,169)$ & 25.8 & 33.8 & 14.5 & 94 & 11.8 & $5-832$ \\
\hline & 6335 & M & 390 & 974 & 47 & 62 & $0.6 / 34$ & 21 & $35.7(1,708)$ & 29.4 & 33.3 & 11.2 & 19 & 9.7 & $16-610$ \\
\hline
\end{tabular}




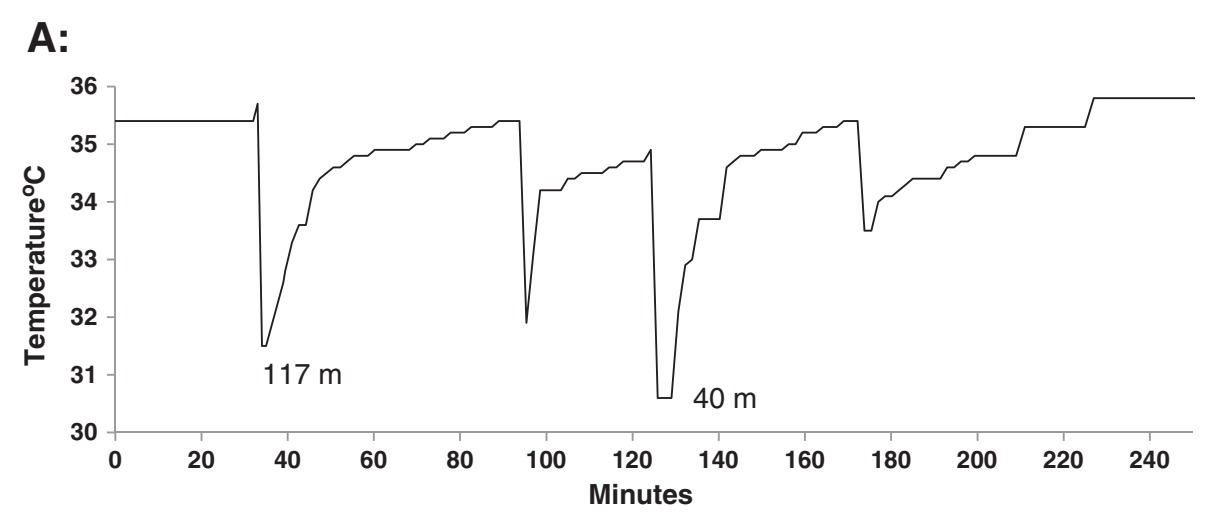

B:

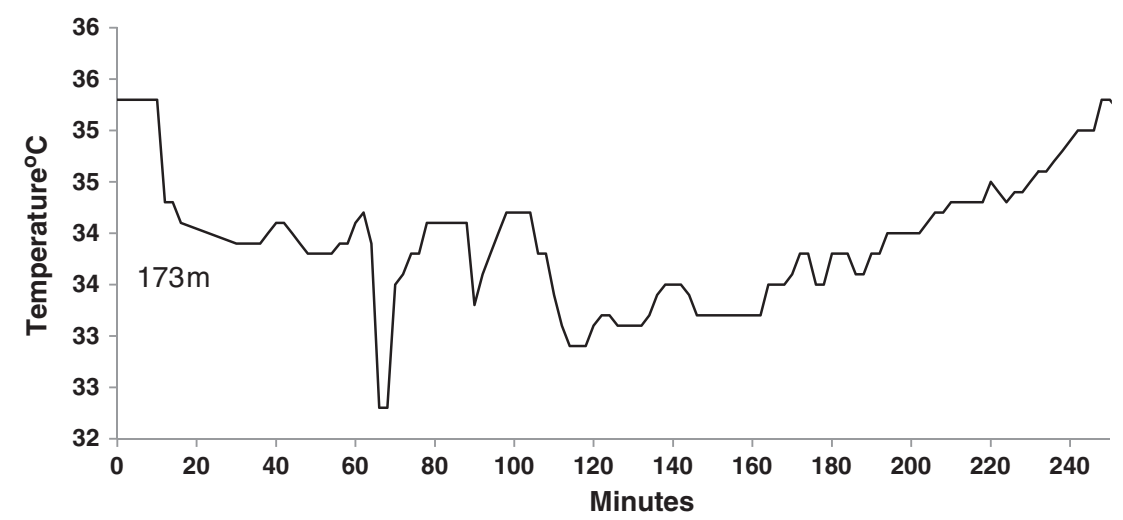

Figure 3 Temperature drops during ingestion events. (A) Example of a sequence of four temperature drops with long-lasting temperature recovery from whale \#24638 (19 Aug. 2012, 12:01). (B) Example of a temperature drop from whale \#3965 (14 Aug. 2013, 15:42) with an initial feeding depth of $173 \mathrm{~m}$ (temperature drop to $34.5^{\circ} \mathrm{C}$ ), three other temperature drops at min 63,89, and 105, and then prolonged recovery of the stomach temperature lasting almost $4 \mathrm{~h}$. Note that depths of temperature drops were not available for all ingestion events.

which is well below the recovery time reported by Kuhn and Costa in feeding experiments with captive elephant seals (Mirounga angustirostris) [10]. After being fed 0.5 to $1 \mathrm{~kg}$ fish $\left(0^{\circ} \mathrm{C}\right)$, the seals experienced a temperature drop of 11 to $12^{\circ} \mathrm{C}$ and a recovery time of 62 to $70 \mathrm{~min}$. Similarly, captive harbor seals (Phoca vitulina) fed 0.1 to $0.2 \mathrm{~kg}$ fish $\left(11^{\circ} \mathrm{C}\right)$ had a temperature drop of $10^{\circ} \mathrm{C}$ and a recovery time of $>20$ min [8]. Considering that narwhals had much smaller temperature drops and shorter recovery times, it seems unlikely that they were ingesting large prey items. This is also in agreement with the small size of the prey $(<100 \mathrm{~g})$ estimated from the stomach contents.

Based on theoretical values of metabolic rates and an energy model, Laidre et al. [18] estimated daily food consumptions of $6 \%$ and $5 \%$ of the body mass for immature males and females, respectively, and 3\% to $4 \%$ of the body mass for adult narwhals in Baffin Bay. The average estimated mass of the tagged whales in this study was $853 \mathrm{~kg}$ ( $\mathrm{SD}=194$, Table 1, Figure 4) and they were all considered mature based on their body length [11]. Therefore, they would be expected to consume close to $31 \mathrm{~kg}^{\text {day }}{ }^{-1}$ according to the theoretical model [18].
The estimated feeding rate in this study is 10 meals per day. Using the Laidre et al. [18] estimate, this corresponds to single meals of $3.1 \mathrm{~kg}$, which seems large when compared to the observed temperature drops, the fast recovery times, and the size of individual prey items. However, compared to the captive animals mentioned above $[8,10]$, free-ranging narwhals presumably have a shorter recovery time due to stomach churning and metabolic heat produced during activity that both will increase the heat transfer to the stomach content. Laidre and HeideJørgensen [13] found that narwhals feed intensively during winter in Baffin Bay but have little feeding activity in the coastal summering grounds. This matches the low food consumption detected in summer for the East Greenland population included in this study and is also supported by samples from a narwhal summering ground in Northwest Greenland that indicate an average meal size of $1.6 \mathrm{~kg}$ or slightly less than the mean mass of stomach contents obtained in this study [12]. Frequency of feeding events is also expected to be affected by the mass of the ingested prey: smaller prey like the squid taken in East Greenland would require many feeding events whereas ingestion of 


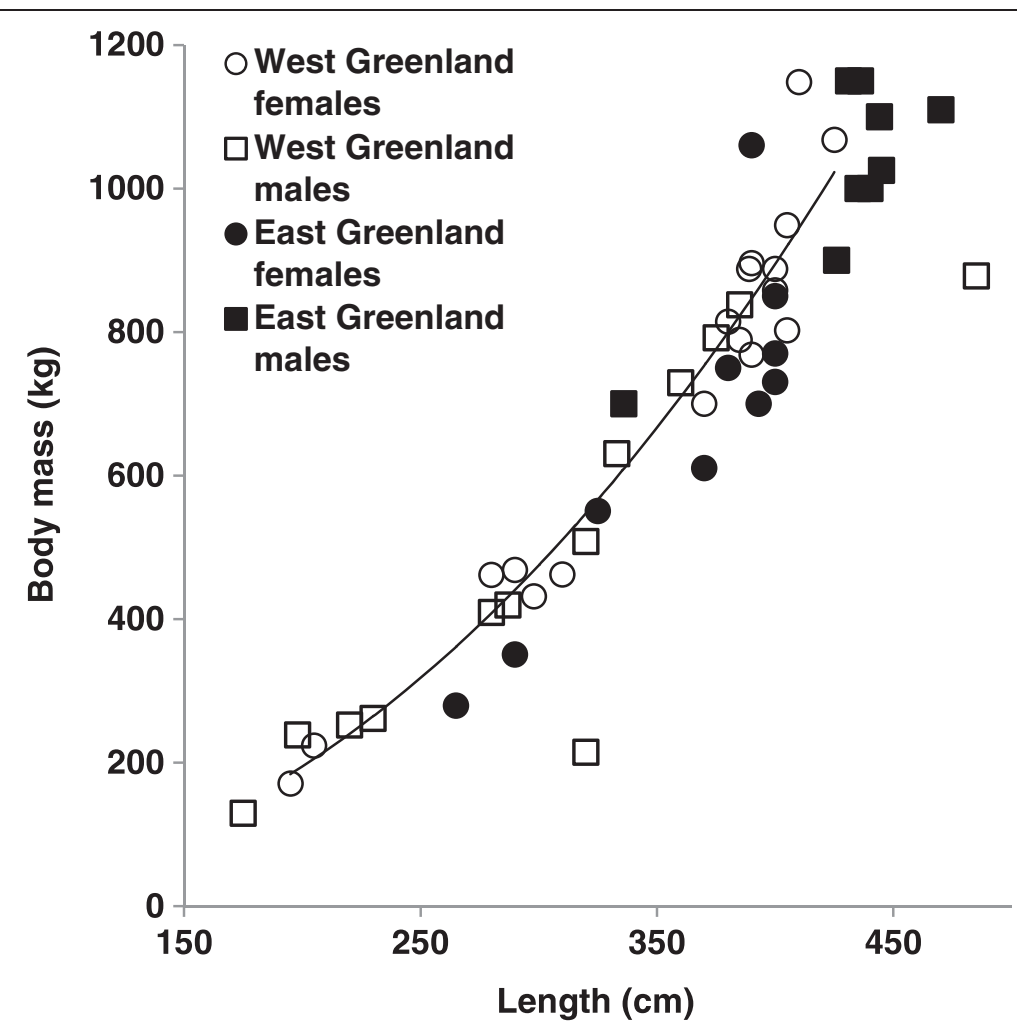

Figure 4 Length-mass relationship for narwhals from West and East Greenland with regression line for both sexes combined. The whales from West Greenland are from [11] and those from East Greenland are from this study. The power functions that predict the mass of narwhals (East and West Greenland combined) instrumented with stomach temperature sensors were: Female: Body mass $=0.003 \times$ Length $^{2.08}$, $r^{2}=0.88$. Male: Body mass $=0.002 \times$ Length $^{2.17}, r^{2}=0.80$.

halibut, as is common in Baffin Bay, would require far fewer feeding events but longer temperature recovery times. Finally, we consider mariposa unlikely for narwhals (and other cetaceans) because they can obtain the water they need from their prey and because of the energetic costs related to heating of ingested water. If it did occur, for example at the brackish river outlets that are omnipresent in Scoresby Sound, it would result in drops in stomach temperature not related to feeding and cause a positive bias in the estimated frequency of feeding events.

The whales administered with STPs had about 10 ingestion events per $24 \mathrm{~h}$ or on average $2.5 \mathrm{~h}$ between presumed feeding events. If we assume that the 31 hunted narwhals whose stomach contents were sampled had the same average feeding rate as the tracked and monitored whales, then the 19 whales with no fresh or recognizable prey in their stomachs out of the 31 whales sampled must have completed the digestion of their last meal in less than approx. $2.5 \mathrm{~h}$ on average. The other 12 whales with prey remains in their stomachs would have been killed $<2.5 \mathrm{~h}$ after consuming their last meal. Such rapid digestion would be consistent with a transit time through the entire alimentary canal of $4.5 \mathrm{~h}$ estimated for captive belugas (Delphinapterus leucas) [2].

\section{Conclusions}

This study represents the first deployment of stomach temperature sensors in free-ranging cetaceans. It demonstrates that even relatively large whales, with body mass exceeding $1,000 \mathrm{~kg}$, can be handled on shore by lifting the body and mouth above sea level so that a stomach temperature sensor can be administered through an intubation tube. In this initial study the STPs were deployed in the esophagus or the esophageal pouch anterior to the esophageal sphincter. It is possible that the two longestlasting STPs ended up passing through the gastrointestinal tract whereas the STPs with short durations were regurgitated. The temperature drop caused by ingested prey is probably larger when the STP is in the upper or lower part of the esophagus than in the pyloric stomach. Nevertheless, the findings presented here suggest that placement of the STPs in the cardiac stomach posterior to the esophageal sphincter should be tested. This placement may extend the duration of the deployment by reducing the risk of vomiting of esophageal content. In the field, penetration with the intubation tube into the cardiac cavity can be detected from the return flow of stomach fluid. Deployment in the cardia will, however, require greater sensitivity to detections of temperature 


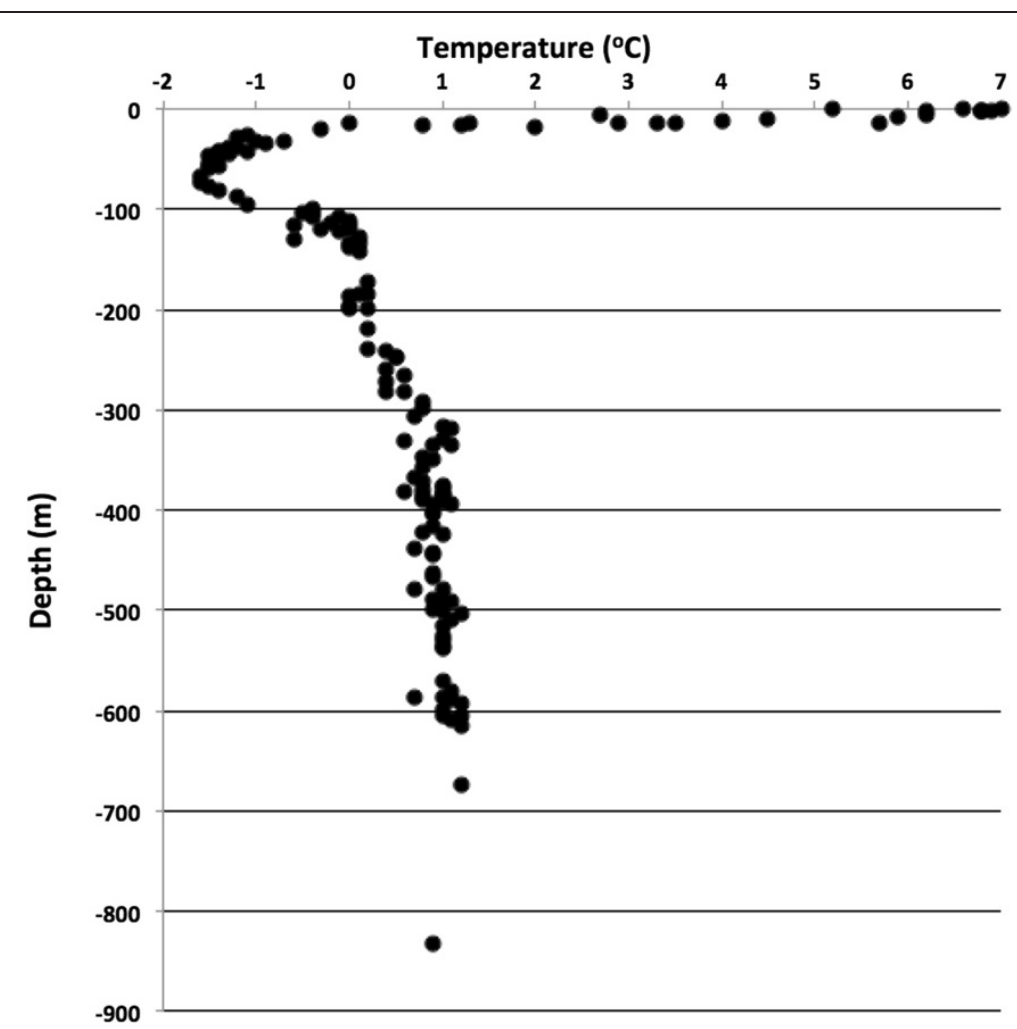

Figure $\mathbf{5}$ Ingestion events in relation to seawater temperature (x-axis) and depth (y-axis). Only data from 2013 are shown because of the better coverage with auxiliary data.

drops as the prey items will have a higher temperature when the prey bolus passes into the cardiac cavity.

This study demonstrates that drops in stomach temperature, presumably caused by prey ingestion, can start within a few hours after the whale has been released, indicating that the handling and instrumentation did not compromise the whale's ability to feed. The whales with STPs were tracked by satellite for $>1$ month after the STPs were ejected/regurgitated, and they were accompanying other whales that had been instrumented only with satellite-linked transmitters (no STPs). No difference in movements from the expected pattern was apparent. Thus, the deployment of the STPs did not cause any detectable harm to the whales.

This is the first study that directly estimates the daily number of food consumption events in a free-ranging cetacean and couples this to daily meal size to estimate daily prey consumption. Previous studies of food consumption by whales have been mainly based on modeling of energy requirements (e.g., [1,19-21]) with a few examples of food intake studies in captive whales (e.g., [2-4]). The information on feeding events obtained from the STPs needs validation to account for possible water ingestion (mariposa) and to assess whether feeding events could be missed by the STPs. Concurrent monitoring of the echolocation activity of narwhals equipped with STPs would provide additional information, particularly on the use of buzz rates as foraging indicators [22].

Narwhals move from their winter habitat in deep offshore waters into coastal areas, often in front of glaciers, during the summer months [23]. The reasons for this seasonal relocation are not known but do not seem related to feeding. Apparently, the whales visit and feed in diverse types of habitats including areas with relatively warm water $\left(>1.2^{\circ} \mathrm{C}\right)$. The function of the visits to such areas warrants further study.

The approach presented here offers the possibility of directly estimating the feeding rate of narwhals. It has the potential, if durations of STP deployments can be extended and proper validation is carried out, to provide information on seasonal changes in feeding activity, including the locations and depths of choice for feeding narwhals.

\section{Methods}

Live-capture operations were conducted in Scoresby Sound, East Greenland, from a narwhal study camp at Hjørnedal (Figure 1). Nets were set perpendicular to the shoreline close to the campsite and lookouts for narwhals were maintained day and night. Whenever narwhals were spotted, boats were launched and the nets were checked for captured whales. Captured whales were hauled to the surface and the anchor line was released while the net was 
pulled to shore. A rope around the peduncle secured the whales and rolling was prevented by two persons standing in the shallows on each side of the whale. The mouth and front end of the whale were lifted above the water with a special lifting crane straddling the whale (Figure 2). The crane's four legs were adjustable to account for bottom topography. The legs were connected to a central bar where a chain lift $(\max .1,500 \mathrm{~kg})$ was mounted. A net mounted on a stretcher was pulled under the belly of the whale and the chain lift was used to lift the stretcher with the whale above the water surface. As soon as the mouth was above the water surface, a flexible silicone intubation tube with an external diameter of $26 \mathrm{~mm}$ and internal diameter of $20 \mathrm{~mm}$ was gently pushed through the esophagus into the extended esophagus, also referred to as the esophageal pouch or fore stomach [24]. In 2012, about $1 \mathrm{~m}$ of the intubation tube was inserted, reaching the fore stomach. In 2013, only $60 \mathrm{~cm}$ of the tube were used, leaving the end of it in the middle of the esophagus. A stomach temperature-sensing pill (STP3, Wildlife Computers, Redmond, WA, USA) was administered through the intubation tube with a smaller flexible hose. In 2012, a short STP was deployed (30 g, $4 \mathrm{~cm}$ long, $2 \mathrm{~cm}$ diameter) with a nominal longevity of 1 month, and in 2013 a longer version of the STP was used, with twice the battery capacity $(60 \mathrm{~g}, 8 \times 2 \mathrm{~cm})$.

The whale was lowered below the surface as soon as the intubation tube was pulled out. The whole operation took about $5 \mathrm{~min}$. After deployment of the STP a satellite transmitter (Splash10-L, Wildlife Computers, Redmond, WA, USA) was mounted with two (in 2012) or three (in 2013) 8-mm nylon pins. Using a cork borer, the pins were pushed through the blubber of the dorsal area right in front of the dorsal ridge, following techniques previously described for instrumentations of narwhals [25]. The transmitters were secured to the nylon pins with stainless steel wires that were locked with stainless steel wire crimps (thalorites).

The STPs were cast in epoxy with four thermistors connected to a titanium ring to ensure quick response time. The temperature sensors operated in the range 0 to $50^{\circ} \mathrm{C}$ with a sensitivity of $0.1^{\circ} \mathrm{C}$ and a precision of $\pm 0.3^{\circ} \mathrm{C}$. Every $20 \mathrm{~s}$ (2012) or $45 \mathrm{~s}$ (2013) the four thermistors measured the stomach temperature and the lowest of the four readings was transmitted as a coded message in the form of an electromagnetic pulse. The lowest of the four temperature readings was transmitted because, as the STP rotates inside the stomach, the lowest temperature is assumed to be closest to the freshly ingested prey material and to be the least affected by contact with the stomach wall. Signals from the STPs were monitored by the satellite transmitters, which also stored, compressed and encoded the temperature values before the whales were at the surface and the data could be relayed through the Argos Data Collection and Location System. The relayed data included stomach temperature at $2 \mathrm{~min}$ intervals. The temperature sampling was increased to once per minute during ingestion events identified by one of the following two situations: i) a temperature change of more than $5^{\circ} \mathrm{C}$ (2012), $10^{\circ} \mathrm{C}$ (2012), or $0.6^{\circ} \mathrm{C}$ (2013) per minute (Table 1); ii) a temperature below $33^{\circ} \mathrm{C}$ (2012) or $34^{\circ} \mathrm{C}$ (2013). In addition to the stomach temperature readings, the dorsally mounted satellite transmitter provided auxiliary information on depth at the start and end of ingestion events, and an externally mounted thermistor on the satellite transmitter read the external temperature at the depth and time of prey ingestions. However, these auxiliary data were not acquired for all ingestion events.

Obvious transmission errors and isolated values of depth or stomach temperatures outside the normal range of values were omitted from further analysis. Classification and enumeration of ingestion events were based on manual examination of temperature drops. Temperature drops below $34^{\circ} \mathrm{C}$ were considered ingestion events independent of the preset threshold values. Recovery was completed when the temperature had returned to values similar to those just prior to the drop, i.e., $>34^{\circ} \mathrm{C}$.

Geographic positions from the satellite transmitters were collected via the ARGOS system [26,27]. Location qualities were provided by Service Argos and coded based on predicted accuracy. Location quality codes (LQ) were $\mathrm{B}, \mathrm{A}$, and 0 to 3 in order of increasing accuracy, where Service Argos predicts that $68 \%$ of classes 1, 2, and 3 are within $1.0,0.35$, and $0.15 \mathrm{~km}$, respectively, of the actual location [26]. Positions of ingestion events were estimated from coincidence in timing of feeding events and closest locations of good quality $(\mathrm{LQ}=1,2$, or 3$)$. Positions of quality $\mathrm{B}$ were excluded and positions of quality 0 and $\mathrm{A}$ were only used if they were achieved within $2 \mathrm{~h}$ of the feeding event and no positions of higher quality were available. In 2013, the four transmitters were programmed not to transmit between 20:00 and 08:00 GMT (except for the first $24 \mathrm{~h}$ ) in order to conserve battery power. Thus, no positions were available during nighttime in 2013.

In order to estimate the body mass-length relationship of narwhals from East Greenland, whole unopened narwhals taken as part of the Inuit hunt in Scoresby Sound were weighed with the crane lift described above and a TEO crane scale $(0-2,000 \mathrm{~kg} \pm 10 \mathrm{~kg})$. From the same individuals, the entire alimentary tracts were collected. The contents of the extended esophagus were classified as fresh or old remains (cf. [13]), the mass of the content was estimated and fleshy pieces and hard parts (otoliths, vertebrae, crustacean skeletons, or squid beaks) were set aside. Identification of prey was based on examination of otoliths and bones from fish, crustacean skeletons, and lower beaks from cephalopods. Otoliths from polar cod (Boreogadus saida) and Arctic cod (Arctogadus glacialis) in most cases could not be distinguished and were pooled into a single category. 


\section{Ethics}

The capturing and tagging operations were conducted under permission from the Greenland Government (permit \#429926, 3 August 2010).

\section{Competing interests}

The authors declare that they have no competing interests.

\section{Authors' contributions}

$\mathrm{MPHJ}$ conceived of the study and developed the instrumentation and intubation techniques and conducted the fieldwork together with NHN and SBB. RGH prepared the map and MHJ, NHN and SBB prepared the manuscript. All authors read and approved the final manuscript.

\section{Acknowledgements}

This study was funded by the Carlsberg Foundation and by the Greenland Institute of Natural Resources. We thank the hunters in Scoresby Sound for invaluable help with capturing and handling the whales, Asger Moos for developing the narwhal lift, and Hans Christian Schmidt for guiding the capturing operations.

\section{Author details}

${ }^{1}$ Greenland Institute of Natural Resources, Box 570, DK-3900 Nuuk, Greenland. ${ }^{2}$ Greeneridge Sciences, Inc., 6160-C Wallace Becknell Road, 93117 Santa Barbara CA, USA

Received: 31 January 2014 Accepted: 12 May 2014

Published: 21 May 2014

\section{References}

1. Rechsteiner EU, Rosen DAS, Trites AW: Energy requirements of Pacific white-sided dolphins (Lagenorhynchus obliquidens) as predicted by a bioenergetic model. J Mammal 2013, 94:820-832

2. Kastelein RA, Ford J, Berghout E, Wiepkema PR, Van Boxsel M: Food consumption, growth and reproduction of belugas (Delphinapterus leucas) in human care. Aquat Mammals 1994, 20:81-97.

3. Kastelein RA, Odell D, Nieuwstraten SH, Wiepkema PR: Food consumption of a captive female killer whale (Orcinus orca). Aquat Mammals 2000, 26:127-131

4. Kastelein RA, Staal C, Wiepkema PR: Food consumption, food passage time, and body measurements of captive Atlantic bottlenose dolphins (Tursiops truncatus). Aquat Mammals 2003, 29:53-66.

5. Wilson RP, Cooper J, Plötz J: Can we determine when marine endotherms feed? A case study with seabirds. J Exp Biol 1992, 167:267-275.

6. Gales R, Renouf D: Detecting and measuring food and water intake in captive seals using temperature telemetry. J Wildlife Manage 1993, 57:514-519

7. Bjørge A, Thompson D, Hammond P, Fedak M, Bryant E, Aarefjord H, Roen $\mathrm{R}$, Olsen M: Habitat use and diving behavior of harbour seals in a coastal archipelago in Norway. In Whales, Seals, Fish and Man. Edited by Blix AS, Walløe L, Ulltang Ø. Amsterdam: Elsevier Science; 1995:211-224.

8. Bekkby T, Bjørge A: Variation in stomach temperature as indicator of mea size in harbor seals, Phoca vitulina. Mar Mam Sci 1998, 14:627-637.

9. Austin D, Bowen WD, McMillan JI, Boness DJ: Stomach temperature telemetry reveals temporal patterns of foraging success in a free-ranging marine mammal. J Anim Ecology 2006, 75:408-420.

10. Kuhn CE, Costa DP: Identifying and quantifying prey consumption using stomach temperature change in pinnipeds. J Exp Biol 2006, 209:4524-4532

11. Garde E, Heide-Jørgensen MP, Ditlevsen S, Tvermosegaard KT, Harding K, Hansén J, Hansen SH: Population dynamics of narwhals Monodon monoceros from East and West Greenland. Polar Res 2014, In press.

12. Heide-Jørgensen MP, Dietz R, Leatherwood S: A note on the diet of narwhals (Monodon monoceros) in Inglefield Bredning (NW Greenland). Meddr Grønland, Biosci 1994, 39:213-216.

13. Laidre KL, Heide-Jørgensen MP: Winter feeding intensity of narwhals (Monodon monoceros). Mar Mam Sci 2005, 21:45-57.

14. Wilson RP, Pütz K, Grémillet D, Culik BM, Kierspel M, Regel J, Boat CA, Lage J, Cooper J: Reliability of stomach temperature changes in determining feeding characteristics of seabirds. J Exp Biol 1995, 198:115-1135.
15. Kristensen TK: Biology of the squid Gonatus fabricii (Lichtenstein, 1818) from West Greenland waters. Meddr Grønland, Biosci 1984, 13:3-17.

16. Santos MB, Pierce GJ, Smeenk C, Addink MJ, Kinze CC, Tougaard S, Herman J: Stomach contents of northern bottlenose whales Hyperoodon ampullatus stranded in the North Sea. J Mar Biol Assoc UK 2001, 81:143-150.

17. Clarke MR: A Handbook for the Identification of Cephalopod Beaks. Oxford, UK: Clarendon Press; 1986.

18. Laidre KL, Heide-Jørgensen MP, Jørgensen OA, Treble MA: Deep-ocean predation by a high Arctic cetacean. ICES J Mar Sci 2004, 61:430-440.

19. Welch HE, Crawford RE, Hop H: Occurrence of Arctic cod (Boreogadus saida) schools and their vulnerability to predation in the Canadian high Arctic. Arctic 1993, 46:331-339.

20. Hooker SK, Whitehead H, Gowans S: Ecosystem consideration in conservation planning: energy demand of foraging bottlenose whales (Hyperoodon ampullatus) in a marine protected area. Biol Conserv 2002, 104:51-58.

21. Noren DP: Estimated field metabolic rates and prey requirements of resident killer whales. Mar Mam Sci 2010, 27:60-77.

22. DeRuiter SL, Alexander B, Blanchet M-A, Hansen SF, Kristensen JH, Madsen PT, Tyack PL, Wahlberg M: Acoustic behaviour of echolocating porpoises during prey capture. J Exp Biol 2009, 212:3100-3107.

23. Heide-Jørgensen MP, Richard P, Dietz R, Laidre K: A metapopulation model for Canadian and West Greenland narwhals. Anim Conserv 2013, 16:331-343.

24. Woodhead GS, Gray RW: On the stomach of the narwhal (Monodon monoceros). Proc R Soc Edin 1889, 16:792-807.

25. Dietz R, Heide-Jørgensen MP, Richard P, Orr J, Laidre K, Schmidt HC: Movements of narwhals (Monodon monoceros) from Admiralty Inlet monitored by satellite telemetry. Polar Biol 2008, 31:1295-1306.

26. Argos S: Guide to ARGOS System. Service Argos Inc. Toulouse: CLS ARGOS; 1989

27. Harris RB, Fancy SG, Douglas DC, Garner GW, Amstrup SC, McCabe TR, Pank LF: Tracking wildlife by satellite: current systems and performance. United States Department of the Interior, Fish and Wildlife Service. Fish Wildlife Tech Rep 1990, 30:52

doi:10.1186/2050-3385-2-9

Cite this article as: Heide-Jørgensen et al.: Stomach temperature of narwhals (Monodon monoceros) during feeding events. Animal Biotelemetry 2014 2:9.

\section{Submit your next manuscript to BioMed Central and take full advantage of:}

- Convenient online submission

- Thorough peer review

- No space constraints or color figure charges

- Immediate publication on acceptance

- Inclusion in PubMed, CAS, Scopus and Google Scholar

- Research which is freely available for redistribution 